\title{
The Effect of Services Marketing Mix Dimensions on Attracting Customers and Retaining Them: the Case of Jordanian Insurance Companies
}

\author{
Hameed Al-Debi ${ }^{1} \&$ Dina Fadhil Jihad Al-waely ${ }^{2}$ \\ ${ }^{1}$ Department of Marketing, Al-Zaytoonah University of Jordan, Amman, Jordan \\ ${ }^{2}$ The World Islamic Sciences and Education University, Amman, Jordan \\ Correspondence: Hameed Al-Debi, Prof. of Department of Marketing, Al-Zaytoonah University of Jordan, P. O. \\ box 130, Amman 11733, Jordan. Tel: 962-6-429-1511. E-mail: altaee47@yahoo.com
}

Received: June 29, 2015 Accepted: July 30, 2015 Online Published: September 29, 2015

doi:10.5539/ijms.v7n5p132 URL: http://dx.doi.org/10.5539/ijms.v7n5p132

\begin{abstract}
This study aims at diagnosing services marketing mix dimensions and their effects on attracting customers and retaining them. The questionnaire was distributed to 150 customers from 15 different companies; 107 questionnaires were returned and 100 of them were usable. The study used SPSS to analyse the results to reach the result that there is a positive effect for the services marketing mix dimensions; physical evidence, service providers and process of service providing and their effect on attracting customers and retaining them and establishing mutual trust between insurance companies in the research sample. The research recommends the insurance companies should foster and enhance the process of retaining the current customers and searching for new ones. Also, providing new services that meet and exceed the customers' need achieves mutual benefits for both companies and customers.
\end{abstract}

Keywords: services marketing mix, Jordanian insurance companies, attracting, retention, Amman

\section{Introduction}

Services marketing mix is considered one of the most important tools that of marketing process that measures customers' satisfaction. Moreover, It considers as one of the influencing strengths in achieving a material returns for the customer institutions, profitability, obtaining a competitive advantage, and gaining customers loyalty and trust to be loyal for the company and its products, this shows the success of marketing process in competition environment (Bu-Moarafi, 2006). Marketing mix is not a theory, but a conceptual framework that determines the principal decision making managers make in configuring their offerings to suit consumers' needs (Goi, 2006).

Borden (1964) has developed the concept of services marketing mix for the first time in the 1960s. Since then, he defined the elements of marketing mix (Product, Price, Place (distribution), and promotion) in which specialized only with industrial sector. This due to his addressing the marketing mix for trainable items, meanwhile he didn't include services that have high degree of intangibility. Later on, McCarthy (1964) came with a developed model for service marketing mix, in which he mentioned the point that this mix is not fit all institution, meanwhile each institution can adapt and modify it in way fits its conditions, and it's potential. Upon that, service marketing mix became a concept that contains seven elements, in which three of these elements were added to suite the nature of service activity, namely: physical evidence, service providers, and process of service providing (Lovelock \& Wirtz, 2011).

\subsection{Study Problem}

Many previous studies have proved that insurance companies in Jordan are not able to fulfil the society's demands of insurance services. These companies started to work for seller's market in which it is contrary to the nature of other institutions and companies that work at the same field in other parts of the world. This in the time that the Jordanian government is seeking to join World Trade Organization (WTO) this to increase the number of institutions and private companies as well increase the intense competition between all of them (Auboin $\&$ Engemann, 2013). This competition cannot be faced unless new creative methods of effective marketing mix and service performance adapted. 


\subsection{Study Questions}

The problem of the study aims to fulfil the following questions:

\subsubsection{The First Main Question}

Do services marketing mix dimensions effect customers' attraction and retention in Jordanian insurance sector? This question includes the following sub-questions:

1. Does physical evidence affect attracting customers and retention them (establishing positive relations with customers, trust) in insurance companies?

2. Do service providers affect attracting customers and retaining them (establishing positive relations with customers, trust) in insurance companies?

3. Do processes of service providing affect attracting customers and retention them (establishing positive relations with customers, trust) in insurance companies

\subsubsection{The Second Main Question}

Do service marketing mix dimensions affect attracting customers and retaining in insurance sector based on the variables of (Gender, Qualification, and Expertise)?

\subsection{The Importance of the Study}

The importance of this study emerges for the important role that insurance companies play in providing a great benefit for national economy through investing the collective insurance premiums in public and private projects this using the loans that companies and individuals provide. Moreover, this contributes in the economic development in the country. Insurance is the key component of economic development in countries, this due to its rule in enabling some financial activities that prevent from financial risks (Arkel, 2011). Starting form that, the researchers hope that the results of this study may contribute in the future in achieving important aspects related to identifying services marketing mix dimensions and their effect on attracting customers and retention them as an application on Jordanian insurance companies. Our Model of study illustrated the causality and effect between the dependent and independent variables (Figure 1.)

Dependent variable

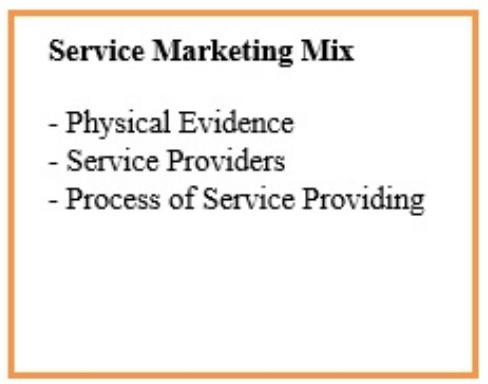

* based on literature Review and previous studies
Independent Variable

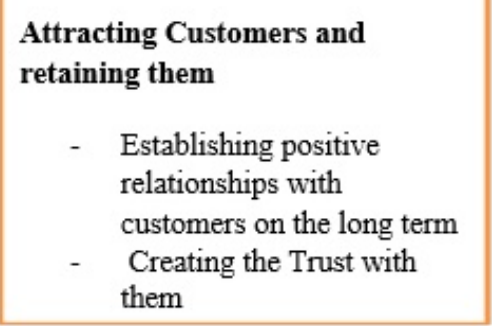

Figure 1. The study model

\subsection{The Study Hypotheses}

The hypotheses were formulated as the following:

HO1: There is no statistical significant at the significant level of $(\alpha \leq 0.05)$ for services marketing mix dimensions on attracting customers and retaining them in insurance companies. This branches into:

1. There is no statistical influence at the significant level of $(\boldsymbol{\alpha} \leq \mathbf{0 . 0 5})$ for physical evidence on attracting customers and retaining them (establishing positive relations with customers, trust) in insurance companies.

2. There is no statistical effect on the significant level of $(\boldsymbol{\alpha} \leq \mathbf{0 . 0 5})$ for service providers on attracting customers and retaining them (establishing positive relations with customers, trust) in insurance companies

3. There is no statistical effect on the significant level of $(\boldsymbol{\alpha} \leq \mathbf{0 . 0 5})$ for processes of service providing on attracting customers and retaining them (establishing positive relations with customers, trust) in insurance companies 
HO2: There is no statistical significant influence on the significant level of $(\alpha \leq 0.05)$ for services marketing mix dimensions on attracting customers and retaining them in insurance companies due to the variables of (Gender, Qualification, and Expertise).

\subsection{The Terms of the Study}

Services Marketing Mix are group of marketing tools that institution use to achieve marketing goals in the target market that leads to a relative reaction aims at meeting customers' expectations and satisfy them. It represents a set of tools by which entities achieve their marketing goals in their target markets (Al-Dmour \& Ayesh, 2005, p. 106; Alvedari, 2006). This ramifies into:

- Physical Evidence: the interest of marketing men in making the service acquiring a suitable level of quality. This in order to be close to the material trainable element through tools and equipment that are used in service producing (Richard et al., 2005, p. 170; Al-Bakri, 2006, p. 221).

- Service Providers: are the workers on providing services to customers that may consider important in developing long-term relations with the customers, even the purchasing was not achieved on the near time (Abu Mandil, 2008, p. 62). According to Dargi (2009, p. 195) it represents the Personnel which are the main and only component in providing services for customers.

- $\quad$ Process of Service providing: represents the level of the efficiency in offering and providing the service. This seems less important regarding the material products or items (Abu Mandil, 2008, p. 15).

Attracting Customers and Retaining the Customers: represents the ability to keep customers satisfy of the service, as well, keeping the products on the specifications and meet the customers' expectations (Armstrong \& Kotler, 2004, p. 11). This ramifies into:

- Establishing Positive Relations with Customers on the Long Term: the process of establishing friendly linkages with the customers, in a way creates positive feelings toward the company or the service to guarantee their satisfaction. Such relations make customer gratitude and loyalty increase in which lead to keep costumers for long time (Morales, 2005, p. 26).

- Trust: is defined as the core of keeping on demanding the products of services for the company (AL Mustafa, 2013, p. 305).

\section{Literature Review}

Recently, many new concepts have emerged in which contain modern marketing strategies proved as essential elements to achieve companies success and stay in a competitive work environment namely, customers relations and loyalty and customers relations management (CRM). CRM represents the strategic use of information, process, technology and individuals to establish relationships with customers in a way achieves the institution goals. It represents a strategy for keeping customers and forstering the bonds with them through its main process that includs all functions with direct contact with clients ( Al-Mansour, 2006)

This study adapts variaus modern concepts, ideas, theories, indications and statistical tests to identify services marketing mix dimensions and their effect on attracting customers and retention them: applied in insurance companies in Jordan, a developing country.

\subsection{Theoretical Review}

\subsubsection{The Concept of Service Marketing Mix (SMM)}

SMM represents a group of relevant and correlated actions that each depends on the other in order to perform marketing function as it is planned to be by Marketing managers. The last ones find themselves in facing many options that are related to four elements of SMM. SMM is known for marketing men as "a Mix of marketing actions that can be controlled by institution and presented to specific market sector of customers" (Ismaeel, 2005, p. 59).

It has defined as "marketing variables that define the organization or institution's management. This includes product, place and promotional price. Marketing mix is considered an overall-level concept but a partial level one" (Bazreah, 2000, p. 18).

SMM is important to develop services marketing program. As a consequence it leads to an alternative model, which included internal marketing, benefit development, product development, targeting, channels, differentiation, selling and positioning (Akroush, 2011; Hassan et al., 2013).

Marketing Mix represents "the primary basis that is more movable and cabable in which can goes with other special variables of marketing action, especailly bussenisse cycle in its different stages" (Al-Khuderi, 1996, p. 
102). Marketing Mix is the combination of four elements, called the 4P's (Product, Price, Promotion and Place), that every company has the option of adding, subtracting, or modifying in order to create a desired marketing strategy (Londre, 2009). It has defined as a collection of choices that represent and clarify the view of the company for the target market.

As well as represents the place that determines the offer that will be presented to customers (Product, service) and the way to price, promote, and distribute it. In order to achieve an efficiency for both marketing mix and each element of its essential ones, it is important to make its policy and methods based on general strategies that are set by company for different important matters. As well, to be set in the light of information and studies that held on customers (Abu Mandil, 2008, p. 62).

The elements of marketing mix produce during its interaction and coordination motivating force. The force moves toward a positive action to be out of the recession that may occur due to the lack of control on theses four elements that can fail the projects and its actions. Moreover, these elements play an genuine role to transfer the crises to move forward development and creativity. Marketing mix take in its last stage marketing path which represent the final process of market analysis and choosing market sector and positioning. These Four elements are used to affect customer's behavior.

Some researchers and scholars in marketing agree on that marketing mix consists of four main elements (4ps) which are: Product, Price, promotion, and place or distribution (Barion, 2006). Meanwhile, when it comes to the field of services, There new elements were added to be modified into (7ps) those three added elements are: Providers, physical evidence, and process of providing service (Ivy, 2008; Al-taee \& Al-alaak, 2008).

Recently, many companies started to realize the importance of the role that marketing actions play in making its goals and policy successful. Moreover, these companies can be able to work in the market without these actions. This importance for marketing and marketing actions represent the great conflict between many companies in order to survive and continue its work in the market. Due to this, the study of marketing mix reality in companies and commercial banks gained its importance (Abu-Znaid \& Al-Sherif, 2009).

Regarding to Lovelock \& Wirtz (2011) \& Palade (2011) Marketing mix consists of the following elements:

1) Product/ service.

2) Price

3) Place and time of distribution

4) Promotion

5) Process of providing service

6) Quality and productivity

7) People ( customers)

8) Physical evidence

The marketing science (generally), elements of marketing mix (especially) can be benefited in promoting information services to companies. The importance of the companies emerged due to its role in providing services to all society categories. As well as, the company provide these services to a wide base of benefited individuals, it has to identify their needs and works on fulfilling them, this represent the core of marketing (Al Murad \& Hassan, 2009; Al-Taee \&Al-Alaak, 2008).

\subsubsection{The Dimensions of Service Marketing Mix}

\section{Service promotion}

Researchers in the field of marketing believe that the general definition of service promotion based on marketing actions and processes that aim at providing intangible benefits that meet customer's need through a way of exchange (Da'aboul \& Mohammad, 2003).

\section{Physical evidence}

Physical evidence controbuts in creating the company's character. This is an essencial factore distingueshes the company from other competetive companies in the market. Banks, airlines companis and other companies which provied products know that they are disingushed from others regarding the raw elements in their work. Those companies sell the same product or service with the samle price, as well they provid the same amount og services. This is the main freature that distingues airline companies from other in which represents its character. In other words, this showes the way or form that presents companies character (Al-Dmour \& Ayesh, 2006). 
Physical evidence represents the intangibility of service products that makes it difficult for consumers to evaluate service offerings, particularly quality and value for money, prior to purchase. Physical evidence includes aspects such as the service provider's building/facilities and staff appearance, promotional materials and branding strategies (Ikechukwu etal, 2012).

\section{Attracting customer}

In context of modern business companies, the traditional methods of attracting customers are not that effective with existence of high-competitive environment. The good understanding of customer's motivation, attitude, cost and profitability is considered an important step in order to improve the performance of business companies in the light of this environment. Firms devote a large amount of their resources to advertising and promotion, and increasingly to outright customer subsidies this in order to attract them and keep them. Hence, it is important to highlight an important aspect which is Customer retention, in which represents the maintenance of continuous trading relationships with customers over the long term (Anani, 2010; Lymperopoulos et al., 2012)

With the revolution of information technology, especially World Wide Web in which it helped in finding opportunities to business organizations to establish better relations with customers than before. This by combining the capabilities of a direct response to customers' requests with high interaction allows them to establish and support long-term relations with customers (Winer, 2001, p. 1). This is called Customers relations management (CRM). CRM is considered one of the effective solutions that scattered all over the world. It aims to increase customers' satisfaction and gain their loyalty while providing better products with less price. Through linking the functions of marketing, sales, research and development, and customer support services together to go a step further by creating added value for them (Langs, 2002, p. 1).

According to Grant \& Anderson (2004, p. 24), CRM is defined as "strategy, a collection of distinguished programs, and technique that aim at reducing the cost and increasing incomes, and creating new opportunities and channels in order to expand, as well, working of improving customer's value and satisfaction, and profitability and keeping on them".

Reichheld \& Schefter (2002, p. 32) defined CRM as "strategies to build customer's loyalty and increasing profits all the time".

According to Judith $(2003$, p. 4) it represents establishing a relation with the customer during its life stage through strategic use of information, process, technology and individuals in a way achieve the company's goals".

Wikstrom (2003, p. 44) defines it as "philosophy that enhances the value of determined process, and mixing and developing different specifications in the company to reach the (Voice) of customers and adding a high-value to customer in the long-term, as well, specifying current and possible customers' sectors.

\section{Trust}

Trust is considered a fundamental element in dealing with companies. Upon that, companies have to build an environment that enable customers of achieving trust with them and to go forward to benefit from their services. This due to its importance in creating mutual benefits and correlations that can be successful for the long-term period with customers (Balasubramanian et al., 2003).

Establishing the trust through services needs providing protected and safe infrastructure on different levels that customer benefits from away of all external threats that may affect negatively providing the service. It demands as well offering the beneficial with services that based on transparency in dealing and reacting with the. This should be upon the procedures and activities that are applied by the company that provides services in the field of information security and guarantee its privacy (Kim et al., 2003; Rama Yellkur, 2008).

\subsection{Previous Studies}

Reibstein (2002) conducted a study titled by "Attracting Customers to Online Stores and Keeping them". The study aimed at identifying the effect of keeping goof relations with customers and attracting them. The study used analytical method. The results figured out that providing good service for customers and knowing their needs and meeting these needs are the most important elements that lead to establishing positive relations with them. It showed as well that what is difficult in to keep customers and making them need to visit the site on longer term not to visit the site itself.

Mrqash (2007) conducted a study titled by "the importance of service marketing mix in improving insurance services". It aimed at shading the light to the importance of marketing in insurance companies in Algeria in the light of liberating insurance marketing from competition between public and private insurance companies. The study conducted in Algeria using analytical method. The result indicates that there is lake of knowledge of 
insurance culture from the individual this in one side, and the openness of competitive market from another part. This made insurance companies develop the methods of providing their services and increasing marketing efforts according to customers' demands and the privacy of insurance action and services.

Abu Mandil (2008) conducted a study titled "the Actual Practice of Marketing Mix and Its Effect on Customers' Loyalty". It aimed at identifying the actual practice of marketing practice (service, pricing, promotion, and distribution) in Palestine Telecommunication Company (PTco.). As well, to identify its effect on customers' loyalty and to find out the extent of statistical difference of the study sample upon the effect of marketing mix on customers' loyalty, the study used descriptive-analytical method. The sample consisted of 500 clients of PTco in which were chosen randomly. The results indicates that marketing mix that PTco provides has a positive effect and it meet the needs of clients within different levels of marketing mix elements (service, pricing, promotion, and distribution). PTco provides many different services that go with the latest information and telecommunication sector international services that suit different variant segment of society, especially those with limited incomes and want to limit their expenses. Moreover, the study concluded that Marketing mix that PTco uses is considered effective and achieve the goals of reaching different customers through using different tools of promotion.

Monday (2011) conducted a study titled by "A Markov Chain Model Analysis of GSM Network Service Providers Marketing Mix". The study aimed at investigation the effect of using Markov analysis on the choice of service providers and approving out the determinants of marketing mix. The study conducted in Jordan using descriptive-analytical method. The sample consisted of 4 telecomunication companies (Zain, Globalcom, Etisalat \& MTN). The study found out that there are determinants of service marketing mix which are ( Network coverage, tariff, free SMS, connectivity and customer services). As well, it indicated the Markov Chain Model helps in deremining the role of service providers' loyalty in telecommunication companies and their ability to achieve customers' satisfaction. Moreover, the study approved out that the optimum marketing mix among the various service providers were among the various service providers were as follows: MTN 52.5\%, Globacom $27.5 \%$, Zain $15.4 \%$ and Etisalat $4.7 \%$. This was depended to the effeciency of services providers in these companies and their high capability in deaing with price rising and establishing positive long-term relations.

Akroush (2011) conducted a study titled by "The 7Ps Classification of the Services Marketing Mix Revisited: An Empirical Assessment of their Generalizability, Applicability and Effect on Performance-Evidence from Jordan's Services Organizations". The study aimed at investigating generalizability of service marketing mix (SMM) and figuring out the effect of SMM on business performance in services organizations. The study conducted in Jordan using analytical-descriptive method. The sample consisted of 146 marketing managers in services organizations'. The study showed that the process has a positive effect on providing physical evidence for services organizations. As well, SMM has a positive effect on the performance of services organization .Moreover, customers are effective predictor on organization performance, through determining prices and promotion' tools of services in which affect financial performance. The managers depend on physical evidence, process and service providers to achieve the needed performance.

AL Debi \& Mustafa (2014), conducted a study titled by "The Impact of service Marketing Mix 7PSin Competitive Advantage to Five Stars Hotel-Case Study Amman Jordan, "The aim of the study is to investigate the impact of service marketing mix 7ps( Product ,Price, Place, Promotion, Physical Evidence, Providers and Process), in achieving of competitive advantage in hotels chain. The study concludes that the (7ps) has a positive effect on the competitive advantage in the hotel industry in Amman. Finally the study recommended to Jordanian hotel management, to using the best available technology of social media such as Facebook and Twitter as marketing tools to attract the locale and international tourists.

\section{Methodology}

\subsection{The Methodology of the Study}

This study has adapted the descriptive- analytical method, this due to its distinguished feature of proving data and information regarding to the problem and explain it well. Using this method enables the researcher from collecting empirical evidences from the study sample.

\subsection{The Population and Sample of Study}

The population consisted of all the clients of insurance companies in Amman Stock Exchange in which are 24 companies. 
Table 1. Study population

\begin{tabular}{ll}
\hline No. & Company Title \\
\hline 1. & Middle East Insurance Co. \\
2. & Al-Niser Al-Arabi Insurance Co \\
3. & Jordan Insurance Company \\
4. & Arabia Insurance Company \\
5. & Delta Insurance Co \\
6. & Jerusalem Insurance Co (Jerco) \\
7. & United Insurance Co. \\
8. & Jordan French Insurance Co (Jofico) \\
9. & The Holy Land Insurance Co. \\
10. & Al Yarmouk Insurance co. \\
11. & Almanara Insurance co. \\
12. & Arab Orient Insurance Co. \\
13. & Jordan Emirates Insurance Co. \\
14. & Arab Life \& Accident Insurance Co \\
15. & Philadelphia Insurance Co. \\
16. & Arab Union International Insurance Co \\
17. & Watania National Insurance Co. \\
18. & Jordan International Insurance (Jiig) \\
19. & The Euro Arab Insurance Group \\
20. & The Islamic Insurance Co \\
21. & Arab Assurers Co. \\
22. & Arab Jordanian Insurance Group \\
23. & The Mediterranean \& Gulf Insurance Co. -Jordan \\
24. & First Insurance Co. \\
\hline
\end{tabular}

Source: Amman Stock Exchange, 2015.

The questionnaire was distributed on 150 customers from 15 companies in which were randomly selected. 107 questionnaires were returned and 100 of them were considered valid for the study purposes meanwhile 7 questionnaires were not valid to be obtained in the research process. Upon that the Purposive sample consisted of 100 clients from the sample of the study.

Table 2. Study sample

\begin{tabular}{ll}
\hline No. & Company Title \\
\hline 1. & Middle East Insurance Co. \\
2. & Al-Niser Al-Arabi Insurance Co \\
3. & Jordan Insurance Company \\
4. & Jerusalem Insurance Co (Jerco) \\
5. & United Insurance Co. \\
6. & Al Yarmouk Insurance Co. \\
7. & The Islamic Insurance Co \\
8. & Arab Jordanian Insurance Group \\
9. & Delta Insurance Co \\
10. & Jordan French Insurance Co (Jofico) \\
11. & Arab Orient Insurance Co. \\
12. & Arab Life \& Accident Insurance Co \\
13. & Philadelphia Insurance Co. \\
14. & Watania National Insurance Co. \\
15. & Jordan International Insurance (Jiig) \\
\hline
\end{tabular}

\subsection{Questionnaires Study}

A questionnaire was established, in which consists two main parts. The first part concerns with demographic variables which are (gender, qualification, and expertise). The second parts contains two main domains and 5 different fields that test the independent variables which are services marketing mix dimensions (physical evidence, service providers, and the process of service providing). As well they test the dependent variable which is attracting customers and keeping them. 


\subsubsection{The First Domain}

Service Marketing Mix, this includes the following areas:

The First area: physical evidence,

The Second area: service providers,

The Third area: process of service providing.

\subsubsection{The Second Domain}

Attracting customers and retaining them, this includes the following areas:

The First area: Establishing positive relations with customers on the long term

The Second area: Trust

Each item in the second domain has a list of the following statements (Strongly agree, Agree, Neither agree nor disagree, Disagree, Strongly Disagree).

Each of the previous items is given degree in order to be statistically analytical upon the following (Strongly agree (5 degrees), Agree (4 degrees), neither agree nor disagree (3 degrees), Disagree (2 degrees), strongly Disagree (1 degree)).

\subsection{Validity and Reliability of the Instrument}

The researcher has established the questionnaire in its final version, after highlighting some previous studies related the subject of this study. Then it was judged through reviewing it by some specialist in scientific research. Their comments and recommendations were taken into consideration to modify the questionnaire to have its final shape. To check the reliability of the questionnaire, the researcher calculated Cronbach's Alpha for all the areas to test the reliability for each area which was (0.949). This indicates the stability of the results for this study.

\section{Study Procedures}

After checking the reliability and validity of the study, as well, determining the needed sample to implicate this study, the researcher distributed both instruments on a sample consisted of 15 commercial companies that work in the field of marketing activity for financial services.

The degree of practice was divided into three levels, as follows:

- $\quad$ Low level: the means are between (1-2.33).

- Medium level: the means are between (2.34-3.67).

- $\quad$ High level: the means are between (3.68-5).

The following measurement is used to analyze data:

Maximum limit of the scale - Minimum limit of the scale/ No. criteria $=$

$5-1=3 / 4=1.33$ the length of criteria. Upon that the score will be:

- $\quad$ Low (1.00-2.33)

- $\quad$ Medium (2.34-3.67)

- $\quad$ High (3.68-5.00) score

\subsection{Statistical Analysis}

The researchers used Statistical Package for the Social Sciences (SPSS) the process of analyzing, testing the hypotheses by using the following tests:

- T-Test: is used to make binary comparisons in the study hypotheses to check the statistical significance for the results. As well, figuring out the differences due to the variables of (gender, qualification).

- One way ANOVA: It is used to check if there is significant differences in the sample response due to the variables of (Personal and career elements) for the sample.

- Scheffe': is used to check the used to check the resources of the significant Scheffe' test was performed to check for whom the difference in the study sample that is related to demographic and personal variables.

- Simple Regression Test: it is used to test the effect of the independent variable on the dependent variable. 


\section{Results}

\subsection{The Sample Description}

Table 3 shows that male participant reached (48\%) while female participant were (52\%). As well, the table shows that those who have diploma were $(8 \%)$ and for bachelor were $(56 \%)$ and for master were $(27 \%)$ and for $\mathrm{PhD}(9 \%)$. It shows as well, that those who have less than 3 years were (53) and for who have 3- less than 6 years were $(47 \%)$.

Table 3. Demographic characteristics for the study sample

\begin{tabular}{llll}
\hline Variable & Category & Frequency & Percentage \\
\hline Gender & Male & 48 & $\% 48.0$ \\
& Female & 52 & $\% 52.0$ \\
Qualification & Total & 100 & $\% 100$ \\
& Diploma & 8 & $\% 8.0$ \\
& Bachelor & 56 & $\% 56.0$ \\
& Master & 27 & $\% 27.0$ \\
& PhD & 9 & $\% 9.0$ \\
Expertise & Total & 100 & $\% 100$ \\
& Less than 3 years & 53 & $\% 53.0$ \\
& 3- less than 6 years & 47 & $\% 47.0$ \\
& Total & 100 & $\% 100$ \\
\hline
\end{tabular}

\subsection{Question One}

"Do services marketing mix dimensions and have an effect on attracting customers and keeping them insurance companies?"

To answer this question simple-Regression analysis was used to check the effect of marketing mix dimensions on attracting customers and keeping them insurance companies as it is shown in table 4 .

Table 4. Simple-regression test to check effect of marketing mix dimensions on attracting customers and keeping them insurance companies

\begin{tabular}{|c|c|c|c|c|c|c|c|c|}
\hline \multirow[t]{2}{*}{ Dependent Variable } & \multirow[t]{2}{*}{$\mathrm{R}$} & \multirow[t]{2}{*}{ R2 } & \multirow[t]{2}{*}{$\mathrm{F}$} & \multirow[t]{2}{*}{$\mathrm{DF}$} & \multicolumn{4}{|c|}{ Regression Coefficients } \\
\hline & & & & & $\begin{array}{l}\text { Independent } \\
\text { Variable }\end{array}$ & $\mathrm{B}$ & $\mathrm{T}$ & Sig \\
\hline $\begin{array}{l}\text { Attracting customers and } \\
\text { keeping them }\end{array}$ & .801 & .642 & 176.007 & 99 & $\begin{array}{l}\text { Marketing mix } \\
\text { dimensions }\end{array}$ & 0.907 & 13.267 & .000 \\
\hline
\end{tabular}

Table 4 shows the effect of service marketing mix dimensions on attracting customers and keeping them in insurance companies. the results indicates there is a significant effect for mix dimensions on attracting customers and keeping them in insurance companies the significance level was $(0.00)$ which is considered significant on the level ( 0.05$)$. Meanwhile, the value of $R$ was $(0.801)$ on the significance level $(\alpha \leq 0.05)$ and $R^{2}$ reached (0.642). As it shown from the table above, the value of $\mathrm{R}$ can be explained due to the dependent variable and other conditions.

\subsubsection{The First Sub-Question}

"Does physical evidence affect attracting customers and keeping them (establishing positive relations with customers, trust) in insurance companies?"

To answer this question simple-Regression analysis was used to check the effect of physical evidence on attracting customers and keeping them insurance companies as it is shown in table 5 . 
Table 5. Simple-regression test to check effect of physical evidence on attracting customers and keeping them insurance companies

\begin{tabular}{|c|c|c|c|c|c|c|c|c|}
\hline Dependent Variable & $\mathrm{R}$ & R2 & $\mathrm{F}$ & $\mathrm{DF}$ & Regression Coefficient & & & \\
\hline & & & & & Independent Variable & $\mathrm{B}$ & $\mathrm{T}$ & Sig \\
\hline $\begin{array}{l}\text { Attracting customers and keeping } \\
\text { them }\end{array}$ & .629 & .396 & 64.282 & 99 & $\begin{array}{l}\text { Physical } \\
\text { Evidence }\end{array}$ & 0.689 & 8.018 & .000 \\
\hline
\end{tabular}

Table 5 shows the effect of physical evidence on attracting customers and keeping them in insurance companies. the results indicates there is a significant effect for physical evidence on attracting customers and keeping them in insurance companies the significance level was $(0.00)$ which is considered significant on the level $(0.05)$. Meanwhile, the value of $\mathrm{R}$ was $(0.629)$ on the significance level $(\alpha \leq 0.05)$ and $\mathrm{R}^{2}$ reached $(0.396)$. As it shown from the table above, the value of $\mathrm{R}$ can be explained due to the dependent variable and other conditions.

\subsubsection{The Second Sub-Question}

"Do affect service providers affect attracting customers and keeping them (establishing positive relations with customers, trust) in insurance companies?"

To answer this question simple-Regression analysis was used to check the effect of services providers on attracting customers and keeping them insurance companies as it is shown in table 6.

Table 6. Simple-regression test to check effect of services providers on attracting customers and keeping them insurance companies

\begin{tabular}{lllllllll}
\hline Dependent Variable & R & R2 & F & DF & Regression Coefficients & & \\
\hline & & & & & $\begin{array}{l}\text { Independent Variable } \\
\text { services providers }\end{array}$ & B & T & Sig \\
$\begin{array}{l}\text { Attracting customers and keeping } \\
\text { them }\end{array}$ & .724 & .524 & 108.007 & 99 & & 0.804 & 10.393 & .000 \\
\hline
\end{tabular}

Table 6 shows the effect of services providers on attracting customers and keeping them in insurance companies. the results indicates there is a significant effect for services providers on attracting customers and keeping them in insurance companies the significance level was $(0.00)$ which is considered significant on the level $(0.05)$. Meanwhile, the value of $\mathrm{R}$ was $(0.724)$ on the significance level $(\alpha \leq 0.05)$ and $\mathrm{R}^{2}$ reached $(00.524)$. As it shown from the table above, the value of $\mathrm{R}$ can be explained due to the dependent variable and other conditions.

\subsubsection{The Third Sub-Question}

"Do affect processes of service providing affect attracting customers and keeping them (establishing positive relations with customers, trust) in insurance companies?"

To answer this question simple-Regression analysis was used to check the effect of processes of service providing on attracting customers and retaining them insurance companies as it is shown in table (7).

Table 7 shows the effect of process of services providing on attracting customers and keeping them in insurance companies. the results indicates there is a significant effect for process of services providing on attracting customers and keeping them in insurance companies the significance level was $(0.00)$ which is considered significant on the level (0.05). Meanwhile, the value of $R$ was $(0.776)$ on the significance level $(\alpha \leq 0.05)$ and $R^{2}$ reached (0. 602). As it shown from the table above, the value of $R$ can be explained due to the dependent variable and other conditions.

Table 7. Simple-regression test to check effect of processes of service providing on attracting customers and keeping them insurance companies

\begin{tabular}{|c|c|c|c|c|c|c|c|c|}
\hline Dependent Variable & $\mathrm{R}$ & $\mathrm{R} 2$ & $\mathrm{~F}$ & $\mathrm{DF}$ & Regression Coefficients & & & \\
\hline & & & & & Independent Variable & $\mathrm{B}$ & $\mathrm{T}$ & Sig \\
\hline $\begin{array}{l}\text { Attracting customers and } \\
\text { keeping them }\end{array}$ & .776 & .602 & 148.394 & 99 & $\begin{array}{l}\text { Process of services } \\
\text { providing }\end{array}$ & 0.671 & 12.182 & .000 \\
\hline
\end{tabular}




\subsection{The Second Main Question}

"Do service marketing mix dimensions effect attracting customers and keeping them insurance companies due to the variables of (Gender, Qualification, and Expertise?"

\subsubsection{First Part: Gender}

To investigate this question t-value was calculated for mean of service marketing mix dimensions on attracting customers and keeping them insurance companies due to the variables of Gender according (male, female) and the result as follow:

Table 8 . Means standard deviations and the t-value for the responses of the sample of the study from males and females

\begin{tabular}{|c|c|c|c|c|}
\hline Group & Gender & Mean & $\mathbf{T}$ & Sig \\
\hline \multirow{2}{*}{ Physical evidence } & Male & 4.07 & -.413 & .680 \\
\hline & Female & 4.13 & & \\
\hline \multirow{2}{*}{ Service providers } & Male & 3.89 & -.633 & .528 \\
\hline & Female & 3.98 & & \\
\hline \multirow{2}{*}{ Process } & Male & 3.71 & .506 & .614 \\
\hline & Female & 3.62 & & \\
\hline \multirow{2}{*}{$\begin{array}{l}\text { Establishing positive } \\
\text { relations with customers }\end{array}$} & Male & 3.66 & .288 & .774 \\
\hline & Female & 3.61 & & \\
\hline \multirow{2}{*}{ Creating Trust } & Male & 3.89 & 1.039 & .301 \\
\hline & Female & 3.72 & & \\
\hline \multirow{2}{*}{ Total } & Male & 3.83 & .326 & .745 \\
\hline & Female & 3.79 & & \\
\hline
\end{tabular}

The results in table 8 indicate that there is no significant at the level $(\alpha<0.05)$ in the sample responses (male and female participants) related to marketing mix dimensions effect on attracting customers and retaining them insurance companies due to the variable of gender. The significant value was more than $(0.05)$ which considered insignificant.

\subsubsection{Second: Qualification}

To investigate this question One Way ANOVA test was performed to check the Effect service marketing mix dimensions on attracting customers and keeping them insurance companies due to the variable of qualification and the result as shown in table 9:

Table 9. ONE WAY ANOVA-test of the effect service marketing mix dimensions on attracting customers and keeping them insurance companies due to the variable of qualification

\begin{tabular}{|c|c|c|c|c|c|c|}
\hline Fields & Source of differences & Sum of Squares & DF & Mean Square & $\mathrm{F}$ & Sig. \\
\hline \multirow{3}{*}{ Physical evidence } & Between Groups & .985 & 3 & .328 & \multirow{3}{*}{.694} & \multirow{3}{*}{.558} \\
\hline & Within Groups & 45.402 & 96 & .473 & & \\
\hline & Total & 46.387 & 99 & & & \\
\hline \multirow{3}{*}{ Service providers } & Between Groups & 2.184 & 3 & .728 & \multirow{3}{*}{1.629} & \multirow{3}{*}{.188} \\
\hline & Within Groups & 42.893 & 96 & .447 & & \\
\hline & Total & 45.078 & 99 & & & \\
\hline \multirow{3}{*}{ Process } & Between Groups & 4.737 & 3 & 1.579 & \multirow{3}{*}{2.175} & \multirow{3}{*}{.096} \\
\hline & Within Groups & 69.685 & 96 & .726 & & \\
\hline & Total & 74.422 & 99 & & & \\
\hline \multirow{3}{*}{$\begin{array}{lr}\text { Establishing } & \text { positive } \\
\text { relations } & \text { with } \\
\text { customers } & \\
\end{array}$} & Between Groups & 5.570 & 3 & 1.857 & \multirow{3}{*}{3.162} & \multirow{3}{*}{.028} \\
\hline & Within Groups & 56.362 & 96 & .587 & & \\
\hline & Total & 61.932 & 99 & & & \\
\hline \multirow{3}{*}{ Creating Trust } & Between Groups & 4.212 & 3 & 1.404 & \multirow{3}{*}{2.314} & \multirow{3}{*}{.081} \\
\hline & Within Groups & 58.253 & 96 & .607 & & \\
\hline & Total & 62.466 & 99 & & & \\
\hline \multirow{3}{*}{ Total } & Between Groups & 3.197 & 3 & 1.066 & \multirow{3}{*}{2.481} & \multirow{3}{*}{.066} \\
\hline & Within Groups & 41.233 & 96 & .430 & & \\
\hline & Total & 44.430 & 99 & & & \\
\hline
\end{tabular}


The table 9 showed that there is no significant at the level $(\alpha<0.05)$ for the all fields this because the significant value was more than $(0.05)$ which considered insignificant except the field of (establishing positive relations with customers on) in which Only the significant value was less than $(0.05)$ and this considered significant. To check the resources of the significant Scheffe' test was performed to check for whom the differences belong as shown in the table (10).

Table 10. Scheffe' Test to check the effect of service marketing mix dimensions on attracting customers and retaining them insurance companies due to the variable of qualification

\begin{tabular}{|c|c|c|c|c|c|c|c|}
\hline Fields & & Category & Mean & Diploma & Bachelor & Master & PhD \\
\hline \multirow{4}{*}{$\begin{array}{l}\text { establishing } \\
\text { relations } \\
\text { customers }\end{array}$} & \multirow{4}{*}{$\begin{array}{r}\text { positive } \\
\text { with }\end{array}$} & Diploma & 4.19 & & & & \\
\hline & & Bachelor & 3.71 & .48214 & & & \\
\hline & & Master & 3.48 & .70602 & $.22388^{*}$ & & \\
\hline & & Phd & 3.14 & 1.04861 & .56647 & .34259 & \\
\hline
\end{tabular}

The Table 10 showed differences and the categories that are significant that marked with $\left(^{*}\right)$ which was to the (Bachelor) in establishing positive relations with customers on.

\subsubsection{Three: Expertise}

To investigate this question t-value was calculated for mean of service marketing mix dimensions on attracting customers and keeping them insurance companies due to the variable of Gender according (less than 3 years, 3less than 6 years) and the result as follow:

Table 11. Means standard deviations and the t-value for the responses of the sample of the study from males and females

\begin{tabular}{lllll}
\hline Group & Expertise & Mean & T & Sig \\
\hline \multirow{2}{*}{ Physical evidence } & less than 3 years & 4.00 & -1.538 & .127 \\
& 3- less than 6 years & 4.21 & & .1 .595 \\
Service providers & less than 3 years & 3.83 & & .114 \\
\multirow{2}{*}{ Process } & 3- less than 6 years & 4.05 & -1.418 & .160 \\
establishing positive & less than 3 years & 3.55 & & \\
relations with customers & 3- less than 6 years & 3.79 & -1.667 & .099 \\
Trust & 3- less than 6 years & 3.51 & -.820 & .414 \\
\multirow{2}{*}{ Total } & less than 3 years & 3.77 & & .119 \\
\hline
\end{tabular}

Note. all results are note significates because less than $(0.05)$.

The results in table 11 indicate that there is no significant at the level $(\alpha<0.05)$ in the sample responses (male and female participants) related to marketing mix dimensions effect on attracting customers and them insurance companies due to the variable of gender. The significant value was more than $(0.05)$ which considered insignificant.

\section{Discussion}

- The results and conclusions related to the sample (demographic variables)

\section{Gender:}

The data showed that the percentage of female was higher than the percentage of male. In which was (52\%). This shows that female participants are more than male participants in these levels.

\section{Qualification:}

The data showed that the percentage of Bachelor was the highest comparing to other categories. In which was $(56 \%)$. This shows that there is a weakness in other academic cadres. 


\section{Expertise:}

The data showed that the percentage of (Less than 3 years) was the highest comparing to other categories. In which was $(56 \%)$. This shows that there is a weakness in accumulating experience.

\section{The First Main Question}

The results indicate there is a significant effect for mix dimensions on attracting customers and retaining them in insurance companies. This due to the importance of marketing mix in attracting customers and retaining them. As well, satisfy their needs and achieving competitive advantage and capitalizing profits in insurance companies.

\section{The first sub-question}

There is a significant effect for physical evidence on attracting customers and retaining them in insurance companies. this due to the significance of physical evidence in achieving the needed level of quality through choosing the needed equipment and tools to produce and provided service that contributes in creating the company's character.

\section{The second sub-question}

There is a significant effect for services providers on attracting customers and retaining them in insurance companies. This can be due to fact that service providers understand well customers motivations, their costs and profits. This can lead to improve the performance of insurance companies.

\section{The third sub-question}

There is a significant effect for process of services providing on attracting customers and retaining them in insurance companies. This due to the efficiency of marketing mix in providing distinguished programs and techniques that help in decreasing costs, increasing inwards, and improving the customers value then increasing their satisfaction and retaining it.

\section{The Second main question}

There are no significant differences related to marketing mix dimensions effect on attracting customers and retaining them insurance companies due to the variable of gender. This due the point of that gender has no effect on the degree of applying the dimensions of service marketing mix for customers. The perspective of the customers is not related to the point if the customer was a male or a female.

There is significant difference related to marketing mix dimensions effect on attracting customers and retaining them insurance companies due to the variable of qualification in favor of (Bachelor). This explains that qualification of customers affect the degree of applying service marketing mix. Due to that, those who hold Bachelor or masters, they apply and practice it in a way differs from those who have $\mathrm{PhD}$.

There are no significant differences related to marketing mix dimensions effect on attracting customers and keeping them insurance companies due to the variable of Expertise. This result can be explained that experience of customers in insurance companies have no effect on applying the dimensions of service marketing mix in these companies. Customers understanding for dimensions of service marketing mix in insurance companies enables them from using these dimensions regardless to the gain experience.

\section{Recommendations}

Upon the results that the study revealed to the researchers recommends with the following:

1. Insurance companies should enhance good relations with customers to establish positive long-term relations.

2. Foster the suitability communication methods with customers that insurance companies use through variety of promotion and communication methods.

3. Improving the culture of insurance for the individualls through developing the Methods of providing service of insurance companies and increasing marketing efforts according to customers' demands.

4. The importance of providing needed material requirements including; Decor, luxurious furniture, computers, and electronic systems in payments processes.

5. Providing qualified and skilful employees with experience, who are able to provide insurance services in a way satisfies customers.

6. Applying modern and updated technical procedures in the process of providing insurance services that suit the norms and traditions of Jordanian society in specific and Arab societies in general. 


\section{References}

Abu Mandil, M. (2008). The Actual Practice of Marketing Mix and Its Effect on Customers' Loyalty /case study Palestine Telecommunication Company - from the perspective of clients. Unpublished Masters Theses. Islamic University, Gaza.

Abu-Znaid, S., \& Al-Sherif, Sh. (2009). The effect of marketing mix on customers' satisfaction / field research on commercial bank in west bank in Palestine. Journal of Al-Aqsa University (S. Humanitarians), 12(1), 212-233.

Akroush, M. (2011). The 7Ps Classification of the Services Marketing Mix Revisited: An Empirical Assessment of their Generalizability, Applicability and Effect on Performance-Evidence from Jordan's Services Organizations. Jordan Journal of Business Administration, 7(1). Retrieved from https://journals.ju.edu.jo/JJBA/article/view/2220/2150

Al Murad, N., \& Hassan, M. (2009). The role of Marketing mix elements on service marketing. Tanmiat Al-Rafidain Publishing, 31(94), 35-53.

Al-Bakri, Th. (2006). Marketing; contemporary concepts. Amman: Yazoory Publishing.

Al-Debi, H., \& Ashraf, M. (2014). The Impact of Services Marketing Mix 7PS in competitive Advantage to Five stars Hotel-Case Study Amman, Jordan. The Institute international Academic Conference, Orlando, Florida, USA $2014 . \quad$ Retrieved from http://www.zuj.edu.jo/wp-content/staff-research/economic/dr.hameed-al-taee/2.pdf

Al-Dmour, H., \& Ayesh, H. (2005). The Effect of the Mix of Marketing Elements of Five Star Hotels on the Perceived Image by the Tourists: A Comparative Study. Jordan Journal of Business Administration, 1(1), 101-121.

Al-Khuderi, M. (1996). Marketing in the Economic stagnation. Egypt: Etrac Publishing.

Al-Mansour, K. (2006). Customer behavior/introduction to advertisement. Dar Al-Hamed, Amman, Jordan.

AlMustafa, S. (2013). The effect of product guarantee service on enhancing customers' satisfaction. Journal of Economic and Law Sciences, 29(1), 291-331.

Al-Taee, H., \& Al-Alake, B. (2008). Services Marketing. Amman, Jordan: Yazoory Publisher. Retrieved from http://www.neelwafurat.com/itempage.aspx\%3Fid\%3Dlbb168377131153\%26search\%3Dbooks

Alvedari, H. (2005). Marketing and Market Management. Payam Noor University, Tehran.

Anani, A. (2010). Attracting and Retaining Customers in South Africa's Banking Sector. Master thesis. Nelson Mandela Metropolitan University. $\quad$ Retrieved from http://etd.uum.edu.my/3480/7/Khaled\%2520Mohamed\%25202013.pdf

Arkell, J. (2011). The essential role of insurance services for trade growth and development. The Geneva association (the international association for the study of insurance economics), research paper. Retrieved from https://www.genevaassociation.org/media/99321/ga2011the_essential_role_of_insurance_services.pdf

Auboin, M., \& Engemann, M. (2013). Testing the Trade Credit and Trade Link: Evidence from Data on Export Credit Insurance. World Trade Organization Economic Research and Statistics Division, Staff Working Paper. http://dx.doi.org/10.2139/ssrn.2229249

Balasubramanian, S., Prabhudev, K., \& Nirup, M. (2003). Customer Satisfaction in Virtual Environments: A Study of Online Investing. Management Science, 49(7), 871-889. http://dx.doi.org/10.1287/mnsc.49.7.871.16385

Barion, K. (2006). The Concept of the Marketing Mix. Presentations on Marketing Management, 1, 2-7. Retrieved from http://eprints.hud.ac.uk/283/

Bazreah, M. (2000). Marketing managment. Egypt: Dar Al Nahda Publishing.

Blois, K. (2000). The oxford textbook of marketing. New York: Oxford University Press.

Bu-Moarafi, B. (2006). Marketing informantion technology in libraries, reviewing the expierence of Al-shargh university experience. Unpublished Masters Theses. King Fahd University, Riyadh.

Da'aboul, M., \& Mohammad, M. (2006). Principals of services marketing. Damascus: Dar Alrida Publishings.

Dargi, P. (2009). Service Marketing Through Iranian Market Perspective. Tehran: Rasa Publications.

Goi, C. (2009). International Journal of Marketing Studies, 1(1), 2. http://dx.doi.org/10.5539/ijms.v1n1p2 
Hassan, G., \& Maedeh, M. (2013). The impact of Direct and Indirect of Internal Marketing on Service Quality and mediating role of OCB. Case: Iran Insurance Company. International Journal of Academic in Business and Social Scinces, 3(11).

Ikechukwu, A., Peace, I., \& Nenaaton, A. (2012). Physical Evidence and Marketing Performance of Commercial Airlines in Nigeria. American International Journal of Contemporary Research, 2(12), 136-149.

Ismaeel, G. (2005). The importacne of internation marketing mix in the performance of internation marketing activity. Unpublished Masters Theses. University of Saad Dahlab, Algeria.

Ivy, J. (2008). A New Higher Education Marketing Mix: The 7Ps for MBA Marketing. International Journal of Educational Management, 22(4), 288-299. http://dx.doi.org/10.1108/09513540810875635

Kim, D., Ferrin, D., \& Rao, H. (2003). Trust and Satisfaction, Two Stepping Stones for Successful E-Commerce Relationships: A Longitudinal Exploration. This paper is accepted for publication in Information Systems Research. An early version of this paper was awarded best paper runner-up at ICIS. Retrieved from http://wings.buffalo.edu/academic/department/som/isinterface/papers/Kim\%2520et\%2520al_ISR.pdf

Kotler, P., \& Armstrong, G. (2004). Principles of Marketing (10th ed.). New Jersey: Prentice Hall. Retrieved from https://vinsontech.files.wordpress.com/2012/04/principles_of_marketing_2814th_edition29.pdf

Londre, L. (2009). Marketing, IMC, Advertising, Promotion, Media and More. Londre Marketing Consultants Publishing.

Lovelock, C., \& Wirtz, J. (2011). Services Marketing: People, Technology, Strategy (Pearson Global Edition). Retrieved from http://www.amazon.co.uk/Services-Marketing-Christopher-Lovelock/dp/0273756060

Lymperopoulos, C., Chaniotakis, I. E., \& Soureli, M. (2012). A model of green bank marketing. Journal of Financial Services Marketing, 17(2), 177-186. http://dx.doi.org/10.1057/fsm.2012.10

Monday, D. (2011). A Markov Chain Model Analysis of GSM Network Service Providers Marketing Mix. International Journal of Engineering \& Technology, 11(4). Retrieved from http://www.ijens.org/Vol_11_I_04/113804-7676-IJET-IJENS.pdf

Morales, A. C. (2005). Giving Firms an 'E' for Effort: Consumer Responses to High-Effort Firms. Journal of Consumer Research, 31(March), 806-812. http://dx.doi.org/10.1086/426615

Mrqash, S. (2007). The Importance of Service Marketing Mix in improving insurance services. Unpublished thesis, Hassiba Ben Bouali University, Algeria.

PALADE, A. (2009). Analysis of Marketing Mix on Cosmetics Products Case Study: Avon Company. Annals of the University of Petroşani, Economics, 11(4), 233-244.

Rama, Y. (2008). Customer Satisfaction and Services Marketing. Journal of Professional Services Marketing, 105-115.

Reibstein, D. (2002). What Attracts Customers to Online Stores, and What Keeps Them Coming Back? Journal of the Academy of Marketing Science, 30(4), 465-473. http://dx.doi.org/10.1177/009207002236918

Wilson, R. M. S., \& Gilligan, C. (2005). Strategic Marketing Management (Planning, implementation \& control) (3rd ed.). London: Jordan Hill.

\section{Copyrights}

Copyright for this article is retained by the author(s), with first publication rights granted to the journal.

This is an open-access article distributed under the terms and conditions of the Creative Commons Attribution license (http://creativecommons.org/licenses/by/3.0/). 